\title{
The new face of rheumatic heart disease in South West Nigeria
}

This article was published in the following Dove Press journal:

International Journal of General Medicine

22 May 2013

Number of times this article has been viewed

\section{Patience Olayinka \\ Akinwusi ${ }^{1,2}$ \\ Johnson Olarewaju Peter ${ }^{2}$ \\ Adebayo Tolulope Oyedeji ${ }^{2}$ \\ Abiona Oluwadamilola \\ Odeyemi ${ }^{2}$ \\ 'Department of Medicine, College of Health Sciences, Osun State University, ${ }^{2}$ Department of Medicine, LAUTECH Teaching Hospital, Osogbo, Osun State, Nigeria}

Correspondence: Patience Olayinka Akinwusi

Department of Medicine, College of Health-Sciences, Osun State University, Oke-Baale, PMB 4494, Osogbo, Osun State, Nigeria

Tel +234803 721 945I

Email pat.akinwusi@uniosun.edu.ng
Purpose: To determine the current prevalence of rheumatic heart disease (RHD), clinical features, types of valvular lesions, complications and mortality, at Ladoke Akintola University of Technology (LAUTECH) Teaching Hospital, Osogbo, South West Nigeria.

Methods: We conducted a retrospective, descriptive study of all the cases of RHD seen in the medical outpatient clinics and wards of LAUTECH for 9 years, from January 2003 to December 2011. Statistical analysis of data obtained was done using SPSS 16.

Results: The total number of attendees of all the medical outpatient clinics during the 9-year period was 67,378, with a subset of 9423 attending the cardiology clinic. There were 11 cases of RHD, which translates to a prevalence of $0.16 / 1000$ and 1.2/1000 for medical outpatient clinics and the cardiology clinic respectively. The mean age of the patients was $25.64 \pm 9.65$ years, age range $14-40$ years and male to female ratio of $1: 1.2$. The most common valve affected was mitral $(90.9 \%)$, followed by the aortic $(36.4 \%)$, and the tricuspid $(18.2 \%)$. Mitral and aortic lesions coexisted in $18.2 \%$ of the patients, and late presentation was common in all RHD cases. Heart failure was the most common complication (90.9\%). Other complications were secondary pulmonary hypertension (36.4\%), infective endocarditis $(27.3 \%)$, atrial fibrillation (27.3\%), cardioembolic cerebrovascular disease (18.2\%), and atrial flutter (9.1\%). Mortality was $9.1 \%$, while only one patient $(9.1 \%)$ had definitive surgery. Financial constraints precluded others from having definitive surgery.

Conclusion: The prevalence of RHD has declined considerably as a result of improvements in the primary health care delivery system, with widespread use of appropriate antibiotic therapy for sore throats resulting in the prevention of rheumatic fever and RHD. However, late presentation is still very common, hence we advocate a more aggressive drive to make the Drakensberg declaration on the control of rheumatic fever and rheumatic heart disease functional in our practice area.

Keywords: rheumatic fever, group A $\beta$-hemolytic streptococcal pharyngitis, valvular lesions, heart failure

\section{Introduction}

Rheumatic heart disease (RHD) is the most serious complication of rheumatic fever (RF), which follows a group A streptococcal infection of the tonsillo-pharynx, and leads to an inflammatory reaction that involves many organs including the heart, joints, and central nervous system. ${ }^{1}$ RHD predominantly affects the mitral valve..$^{2-4}$ Heart failure is the most common cause of morbidity and mortality in RHD, followed by other complications such as native valve infective endocarditis (IE), systemic embolization, pulmonary hypertension, atrial arrhythmias, or complications related to valve surgery. ${ }^{5-7}$

RHD is still a major health problem in Africa especially among children and young adults. ${ }^{8,9}$ The World Health Organization (WHO) reported that acute rheumatic fever and 
subsequent rheumatic heart disease affect about 15.6 million people worldwide. ${ }^{10,11}$ Acute RF is said to be in decline due to widespread use of antibiotics; however RHD remains a major health problem especially in developing countries. ${ }^{6,12}$

In South Africa a very high incidence of $36 \%$ was reported for RHD in the Heart of Soweto Study; ${ }^{13}$ the converse is true in Nigeria as shown by different data emanating from different parts of the country. In the Nigerian Savannah, Sani et al reported a prevalence of $9.8 \%$ of RHD from echocardiography screening from mid-2002 to mid-2006, which is very much lower than that of South Africa. ${ }^{8}$ At the Federal Medical Center, Abeokuta, also in South West Nigeria, Ogah et al reported in an echocardiography study a 3.7\% incidence of RHD out of the 1441 subjects studied. ${ }^{14}$ In our recently concluded 8-year prospective echocardiographic evaluation of 2501 patients presenting in Obafemi Awolowo University Teaching Hospitals Complex, Ile-Ife, South West Nigeria, $3.1 \%$ of the patients had RHD. ${ }^{15}$ In view of these echocardiographic findings from other centers in Nigeria, this present study therefore embarked on a retrospective study to determine the prevalence of RHD, as well as its characteristics, at Ladoke Akintola University of Technology (LAUTECH) Teaching Hospital, Osogbo, South West Nigeria.

\section{Method}

This study was a retrospective and descriptive study involving the review of all medical admission cases, all cases seen at the cardiology clinic, and all the medical outpatient/ specialty clinics of LAUTECH Teaching Hospital (LTH), Osogbo, South West Nigeria, during the 9 years from January 2003 to December 2011. Demographic, clinical, investigation, treatment and follow-up data were retrieved from the case notes of patients identified at the final diagnosis to have RHD.

Statistical analysis was performed with the Statistical Package for Social Sciences (SPSS) Version 16 (IBM Corporation, Armonk, NY, USA). Results were presented in frequencies and percentages. We obtained ethical clearance from the ethical committee of LTH (Ethics number LTH/ REC/04/13/11/06).

\section{Results}

We had a total of 67,378 patients attending our medical outpatient clinics during the 9 years from January 2003 to December 2011; 9423 patients attended the cardiology clinic. We found only 11 cases of RHD, giving a prevalence of $0.16 / 1000$ and $1.2 / 1000$ for all those attending medical outpatient clinics and the cardiology clinic respectively.
Table I Demographic data and past medical history of patients with rheumatic heart disease $(n=I I)$

\begin{tabular}{|c|c|}
\hline Characteristics & Number of patients (\%) \\
\hline \multicolumn{2}{|l|}{ Age range (years) } \\
\hline $\mathrm{II}-20$ & $4(36.4)$ \\
\hline $21-30$ & $5(45.5)$ \\
\hline $31-40$ & $2(18.2)$ \\
\hline \multicolumn{2}{|l|}{ Sex } \\
\hline Male & $5(45.5)$ \\
\hline Female & $6(54.5)$ \\
\hline \multicolumn{2}{|l|}{ Occupation } \\
\hline Student & $5(46.5)$ \\
\hline Civil servant & $2(18.2)$ \\
\hline Artisan & $3(27.3)$ \\
\hline Unemployed & I (9.I) \\
\hline \multicolumn{2}{|l|}{ Marital status } \\
\hline Single & $8(72.7)$ \\
\hline Married & $2(18.2)$ \\
\hline Divorced & I (9.1) \\
\hline \multicolumn{2}{|l|}{ Father's occupation* } \\
\hline Trader & I (9.1) \\
\hline Muslim cleric & I (9.1) \\
\hline \multicolumn{2}{|l|}{ Recurrent sore throat } \\
\hline Yes & $2(18.2)$ \\
\hline No & $9(8 \mid .2)$ \\
\hline \multicolumn{2}{|l|}{ Previous RF } \\
\hline Yes & $2(18.2)$ \\
\hline No & $9(81.8)$ \\
\hline \multicolumn{2}{|l|}{ Past skin sepsis } \\
\hline Yes & I (9.1) \\
\hline No & $10(90.9)$ \\
\hline \multicolumn{2}{|l|}{ Previous invasive procedure } \\
\hline Yes & $0(0)$ \\
\hline No & II (I00) \\
\hline \multicolumn{2}{|l|}{ Past medical history } \\
\hline $\begin{array}{l}\text { Admitted for cough, fever, easy } \\
\text { fatigability at the age of } 7 \text { years }\end{array}$ & I (9.1) \\
\hline Hypertensive for 10 years & I (9.1) \\
\hline Previous history of dyspnea & I (9.I) \\
\hline No past history of any illness & $8(72.7)$ \\
\hline
\end{tabular}

Note: *For pediatric patients.

Abbreviation: RF, rheumatic fever.

Table 1 shows demographic data and past medical history of the patients. The age range of the patients was 14-40 years while the male to female ratio was $1: 1.2$. The mean age was $25.64 \pm 9.65$ years, with a median of 29.0 years and a mode of 15.0 years.

Table 2 shows clinical features of the patients: $90.9 \%$ of the patients had features of heart failure; two (18.2\%) of the patients also presented with cardioembolic cerebrovascular disease (CCVD). Table 3 shows investigation results and valvular lesions seen in the patients. The patient with serial number 3 had IE with vegetations on the aortic valve and the anterior mitral valve leaflet. There was also anterior mitral valve leaflet perforation with mitral regurgitation and severe 
Table 2 Clinical features of patients with rheumatic heart disease

\begin{tabular}{|c|c|}
\hline Clinical features & Number of patients (\%) \\
\hline Fever & I (9.I) \\
\hline Dyspnea & I (9.1) \\
\hline Jaundice & I (9.1) \\
\hline Bilateral pitting pedal edema & $5(45.5)$ \\
\hline Central cyanosis & $\mathrm{I}(9.1)$ \\
\hline Stunted growth & I (9.1) \\
\hline \multicolumn{2}{|l|}{ Pulse rate } \\
\hline$<60$ & $0(0)$ \\
\hline $60-100$ & $5(45.5)$ \\
\hline$>100$ & $6(54.5)$ \\
\hline \multicolumn{2}{|l|}{ SBP } \\
\hline$<140$ & $9(8 I .8)$ \\
\hline$\geq 140$ & $2(18.2)$ \\
\hline \multicolumn{2}{|l|}{ DBP } \\
\hline$<90$ & $8(72.7)$ \\
\hline$\geq 90$ & $3(27.3)$ \\
\hline 个JVP & $4(36.4)$ \\
\hline Cardiomegaly & $8(72.7)$ \\
\hline LPSH & $8(72.7)$ \\
\hline \multicolumn{2}{|l|}{ Murmur } \\
\hline MS & I (9.1) \\
\hline$M R$ & $10(90.9)$ \\
\hline $\mathrm{S}_{3}$ & $9(81.8)$ \\
\hline \multicolumn{2}{|l|}{ Chest } \\
\hline Fine bibasal creps & $3(27.3)$ \\
\hline Wd coarse creps & I (9.1) \\
\hline Normal BVS & $5(45.5)$ \\
\hline $\mathrm{BB}+$ bilateral creps & I $(9.1)$ \\
\hline Creps LUZ & I (9.1) \\
\hline \multicolumn{2}{|l|}{$A B D$} \\
\hline DSAV & I (9.1) \\
\hline Tender hepatomegaly & $9(8 \mid .8)$ \\
\hline Splenomegaly & $4(36.4)$ \\
\hline Ascites & $4[$ I massive] $(36.4)$ \\
\hline \multicolumn{2}{|l|}{ CNS } \\
\hline R hemispheric cardio-embolic CVD & I (9.1) \\
\hline L hemispheric cardio-embolic CVD & I (9.I) \\
\hline
\end{tabular}

Abbreviations: SBP, systolic blood pressure; DBP, diastolic blood pressure; $\uparrow$ JVP, elevated jugular venous pressure; LPSH, left parasternal heave; MS, mitral stenosis; $M R$, mitral regurgitation; $S_{3}$, third heart sound; Creps, crepitations; Wd, widespread; BVS, bronchovesicular breath sounds; BB, bronchial breath sound; LUZ, left upper zone; ABD, abdomen; DSAV, distended superficial abdominal veins; CNS, central nervous system; $R$, right; $L$, left; CVD, cerebrovascular disease.

aortic regurgitation in the same patient, who had a left sided CCVD but no blood culture. The patient with serial number 5 also had IE, with right sided CCVD and positive blood culture for Staphylococcus aureus which was sensitive to ciprofloxacin and ofloxacin, atrial fibrillation, anemia $(\mathrm{Hb} 9.3 \mathrm{~g} / \mathrm{dL})$, neutrophilic leucocytosis (white blood count of $21,700 / \mathrm{mm}^{3}$ and neutrophil of $83 \%$ ), hematuria, and cardiomegaly. The patient with serial number 6 had fever with lobar pneumonia clinically but did not submit to any of the required investigations, blood culture inclusive. A computed tomography (CT) scan of the brain was conducted to confirm the ischemic cerebrovascular disease (CVD) in the two patients with the clinical features of CVD.

Table 4 shows treatment, outcome, and the valvular lesions in the patients. Table 5 shows complications of RHD in the patients and frequencies of the different valvular lesions. All the patients had conservative medical treatment with an anti-heart failure regimen as a mainstay of therapy. This consisted of furosemide, angiotensin-converting enzyme inhibitors, spironolactone, and additional appropriate antihypertensives for the three hypertensive patients. Intranasal oxygen was used when indicated. Digoxin was used in those with atrial flutter, fibrillation, or poor systolic function. Antibiotics were given for 6 weeks to the three patients with infective endocarditis. Enoxaparin was given as an injection to the two patients with CCVD while the partial thromboplastin time was being monitored. Warfarin was also used in those with cardiomegaly, with or without atrial flutter or fibrillation, and their prothrombin time and international normalized ratio were also monitored.

\section{Discussion}

The prevalence of $0.16 / 1000$ for RHD in attendees of our medical outpatient clinics, and 1.2/1000 in attendees of cardiology clinic, shows remarkable reduction in the burden of this serious disease. Previous studies in other centers in Nigeria have shown higher figures. Abengowe in 1979 while studying cardiovascular diseases in northern Nigeria reported a prevalence of $14.4 \% ;{ }^{16}$ Karaye and Sani in 2008 reported a lower prevalence of $7.8 \%$ from the same zone. ${ }^{17}$ Ansa et al also reported a prevalence of $6.0 \%$ out of the 558 patients admitted on account of cardiovascular diseases. ${ }^{18}$ Another study of all cases of heart failure in South Nigeria showed that RHD accounted for $4.26 \%$ of these. ${ }^{19}$ Recent echocardiographic studies across Nigeria have shown a prevalence rate of 3.1\%-9.8\% ${ }^{8,14,15}$ Most of these quoted studies analyzed a subset of medical or cardiac patients and not the total number of cardiology or medical patients seen over a period of time, hence the wide variations in prevalence rates which make comparison of the figures difficult. However all of these prevalence rates/ranges still fall within the estimated prevalence rate of $0.3 \%-18.6 \%$ for developing countries reported by a WHO study group in $1988 .{ }^{20}$ Our current study however sought for RHD among all medical patients and all cardiology patients seen over the period of study, therefore giving a hospitalbased prevalence of RHD in our center. One thing that is clear from all these quoted studies is that the prevalence of RHD is decreasing, and we are of the opinion that improved primary health care delivery, with prompt diagnosis and antibiotic 
Table 3 Investigations of patients with rheumatic heart disease

\begin{tabular}{|c|c|c|c|c|c|}
\hline Patients/age & CXR & ECG & ECHO & BC & VL \\
\hline $\begin{array}{l}I^{*} \\
24 \text { years }\end{array}$ & Not done & $\mathrm{I}^{\circ} \mathrm{AVB}, \mathrm{LVH}$ & MS, LVH, dilated LA, PHT & $\begin{array}{l}\text { No bacterial } \\
\text { growth after } 7 \text { days }\end{array}$ & MS, HHD \\
\hline $\begin{array}{l}2 * \\
14 \text { years }\end{array}$ & $\begin{array}{l}\text { Cardiomegaly } \\
\text { Features of CCF }\end{array}$ & $\begin{array}{l}\text { AFT with varying } \\
\text { degrees of block, } \\
\text { Nonspecific IVCD }\end{array}$ & $\begin{array}{l}\text { Thickened MVL, with slight restriction } \\
\text { of the motion of anterior MVL, } \\
\text { post MVL tethered. Dilated LA and LV, } \\
\text { Depressed systolic function }\end{array}$ & $\begin{array}{l}\text { No bacterial } \\
\text { growth }\end{array}$ & $M R$ \\
\hline $\begin{array}{l}3 \\
30 \text { years }\end{array}$ & NA & NA & $\begin{array}{l}A V \text { endocarditis with severe } A R, \\
A M V L \text { endocarditis with perforation } \\
\text { of } A M V L\end{array}$ & NA & $\begin{array}{l}\text { AR, MR } \\
\text { Aortic and mitral } \\
\text { valve vegetations }\end{array}$ \\
\hline $\begin{array}{l}4^{*} \\
40 \text { years }\end{array}$ & NA & NA & Severe MS, MR, moderate PHT & NA & MS, MR \\
\hline $\begin{array}{l}5 \\
40 \text { years }\end{array}$ & Cardiomegaly & $\mathrm{AF}$ & $\begin{array}{l}\text { Severe MS, moderate MR, } \\
\text { Severe AS, moderate AR, } \\
\text { no intramural clot }\end{array}$ & $\begin{array}{l}\text { Moderate growth } \\
\text { of S. aureus }\end{array}$ & $\begin{array}{l}\text { Severe MS and } \\
A S, \text { moderate } \\
M R \text { and } A R\end{array}$ \\
\hline $\begin{array}{l}6 * * \\
16 \text { years }\end{array}$ & NA & NA & NA & NA & MR (clinical) \\
\hline $\begin{array}{l}7 \\
29 \text { years }\end{array}$ & $\begin{array}{l}\text { Cardiomegaly, } \\
\text { aneurismal dilatation } \\
\text { of RA, features of CCF }\end{array}$ & NA & $\begin{array}{l}\text { MR, congenital discrete } \\
\text { sub-aortic stenosis, severe PHT }\end{array}$ & NA & $\begin{array}{l}\text { MR, congenital } \\
\text { discrete aortic } \\
\text { stenosis }\end{array}$ \\
\hline $\begin{array}{l}8 \\
29 \text { years }\end{array}$ & NA & AF, RVH & Critical MS, AS, TS and TR & NA & $\begin{array}{l}\text { MS, AS, TS and } \\
\text { TR }\end{array}$ \\
\hline $\begin{array}{l}9 \\
30 \text { years }\end{array}$ & NA & $\begin{array}{l}\text { Sinus tachycardia, } \\
\text { LVH with myocardial } \\
\text { strain, AF }\end{array}$ & NA & NA & MR \\
\hline $\begin{array}{l}10 \\
15 \text { years }\end{array}$ & NA & NA & Moderately severe AR, severe PHT & NA & AR \\
\hline $\begin{array}{l}11 \\
15 \text { years }\end{array}$ & Features of $\mathrm{CCF}$ & $\begin{array}{l}\text { LAE, RVH, } \\
\text { nonspecific IVCD }\end{array}$ & MR, TR, PS & NA & $M R, T R, P S$ \\
\hline
\end{tabular}

Notes: *Also hypertensive; **Clinical evidence of infective endocarditis.

Abbreviations: CXR, chest X-ray; ECG, electrocardiography; ECHO, echocardiography; $\mathrm{BC}$, blood culture; $\mathrm{VL}$, valvular lesions; I ${ }^{\circ} \mathrm{AVB}$, I st degree atrio-ventricular block; LVH, left ventricular hypertrophy; MS, mitral stenosis; LA, left atrium; PHT, pulmonary hypertension; HHD, hypertensive heart disease; CCF, congestive cardiac failure; AFT, atrial flutter; IVCD, intraventricular conduction defect; MVL, mitral valve leaflet; LV, left ventricle; MR, mitral regurgitation; NA, not available; AV, aortic valve; AR, aortic regurgitation; AMVL, anterior mitral valve leaflet; AF, atrial fibrillation; AS, aortic stenosis; RVH, right ventricular hypertrophy; TS, tricuspid stenosis; TR, tricuspid regurgitation; LAE, left atrial enlargement; PS, pulmonary stenosis.

Table 4 Treatment, outcome and affected valves in patients with rheumatic heart disease

\begin{tabular}{|c|c|}
\hline Characteristics & Number of patients (\%) \\
\hline \multicolumn{2}{|l|}{ Treatment } \\
\hline Medical & II (100) \\
\hline Definitive surgery* & I (9.I) \\
\hline \multicolumn{2}{|l|}{ Outcome } \\
\hline Alive & $7(63.6)$ \\
\hline Dead & I (9.1) \\
\hline Lost to follow up & $3(27.3)$ \\
\hline \multicolumn{2}{|l|}{ Affected valves } \\
\hline Mitral & $10(90.9)$ \\
\hline Alone & $6(54.5)$ \\
\hline With aortic & $2(18.2)$ \\
\hline With tric and pulm & $I(9.1)$ \\
\hline With aortic and tric & I (9.1) \\
\hline Aortic & $4(36.4)$ \\
\hline Alone & $I(9.1)$ \\
\hline Tricuspid & $2(18.2)$ \\
\hline Pulmonary & I (9.1) \\
\hline
\end{tabular}

Note: *Mitral valve prosthesis. therapy for sore throat and skin sepsis, has had this tremendous impact on the decline of RHD in our practice area. The late Minister of Health Olikoye Ransome-Kuti served during the early/mid 1980s and made primary health care the bedrock of Nigeria's health care. The bases of this included providing primary health centers in all rural areas, training community

Table 5 Complications of rheumatic heart disease

\begin{tabular}{ll}
\hline Characteristics & Number of patients (\%) \\
\hline CCF & $9(81.8)$ \\
LHF & $1(9.1)$ \\
AF & $3(27.3)$ \\
AFT & $1(9.1)$ \\
CCVD & $2(18.2)$ \\
IE & $3(27.3)$ \\
PHT & $4(36.4)$
\end{tabular}

Abbreviations: CCF, congestive cardiac failure; LHF, left sided heart failure; AF, atrial fibrillation; AFT, atrial flutter; CCVD, cardioembolic cerebrovascular disease; $\mathrm{IE}$, infective endocarditis; PHT, pulmonary hypertension. 
extension workers to run these centers, and making essential drugs available, including the penicillin group of antibiotics. Treatment also became free at such centers as well as at secondary health care facilities, with the free health care services run by various state and local governments across the country. Housing conditions have also improved to some extent, however limited. The hospital-based prevalence rate in this study compares favorably with that of Bangladesh which is $1.2 / 1000,{ }^{21}$ and India with a prevalence rate of $1.0-5.4 / 1000 .{ }^{22}$ The mean age of $25.64 \pm 9.65$ years is similar to $24.02 \pm 12.75$ and $29.34 \pm 11.57$ years obtained in studies from the north and southeast of Nigeria respectively ${ }^{2,8}$ thus confirming that it is a disease of children and young adults. ${ }^{8,9}$

Our study shows a male to female ratio of $1: 1.2$, while previous Nigerian studies showed ratios of $1: 1.7^{8}$ and $1: 2^{23}$ thus demonstrating a female preponderance. This finding is supported by other studies from developing countries, such as Egypt and South Africa. ${ }^{24,25}$

Poverty is endemic in Nigeria, due amongst other things to mass corruption and misplaced priorities by our leaders; this has led to elimination of the middle class, hence all the study patients were from a poor socioeconomic background. RHD and RF are related to poverty, overcrowding, poor housing, and shortage of health care resources. ${ }^{26}$ Other evidence of poverty was shown by the inability of the patients to get all the investigations completed, as shown in Table 3, and also the inability to complete definitive surgery.

Childhood history of recurrent sore throat and RF were both present in $18.2 \%$ of the patients, while skin sepsis occurred in only $9.1 \%$ of the patients. Three percent of patients with untreated group A $\beta$-hemolytic streptococcus (GAS) pharyngitis developed $\mathrm{RF}^{27}$ and subsequent or recurrent GAS pharyngitis increases the risk of RF from 3\% to $75 \% .^{28}$ A study in Benin City, Nigeria, showed a streptococcal throat colonization prevalence rate of $9.7 \%$ from groups C, G, B, and F, and not colonization with GAS. ${ }^{29}$ However no study in Africa has linked this non-GAS to RF and RHD. ${ }^{30}$ GAS skin infection (pyoderma) in the Australian aborigines has been linked to RF, but no such link has been found in Africans. ${ }^{31}$

The prevalence of hypertension is very high in Nigeria; its current prevalence in a semi-urban community in the same state (Osun State) as this study center is 36.6\% (calculated using the Joint National Committee on Prevention, Detection, Evaluation and Treatment of High Blood Pressure guidelines VII BP threshold of $140 / 90 \mathrm{mmHg},{ }^{32}$ [13.3\% using BP threshold of $160 / 95 \mathrm{mmHg}^{33}$ ) hence it is not surprising that $27.3 \%$ of the patients had concomitant systemic hypertension (as shown in Table 2). All the patients had conservative medical treatment and only one of them could afford definitive surgery outside Nigeria. This surgery took place in India. Only two centers in Nigeria currently undertake open heart surgery; the service is expensive, and still not well established. The few patients who choose surgery usually source funds from philanthropists, religious organizations, multinational companies, and other public spirited Nigerians through the various media channels.

Mortality was $9.1 \%$ and this occurred in the patient with serial number 5 in Table 3 who had CCVD, S. aureus IE, cardiomegaly, and AF. This mortality was due to late presentation with multiple complications. Also $27.3 \%$ of the patients were lost to follow up. Patients do not usually do well without definitive surgery and so patients and their relations become discouraged and frustrated after spending so much money without getting better; hence they abandon medical treatment and seek help from spiritualists, or resign themselves to fate and die at home.

Heart failure is the most common complication of RHD, and it occurred in $90.9 \%$ of the patients as shown in Table 4. Previous studies also support this finding. ${ }^{5-7}$ CCVD occurred in $18.2 \%$ of the patients, although transthoracic echocardiogram did not detect intramural thrombus; facilities for the more sensitive transesophageal echocardiogram were not available. The two patients with CCVD also had infective endocarditis but one of them had vegetations on the mitral and aortic valves and perforation of the anterior mitral valve leaflet. Seeding of the vegetation into the cerebral arteries could also have resulted in the CCVD, as could dislodgement of portions of an intramural thrombus into one of the cerebral arteries.

Pulmonary hypertension was the most common complication after heart failure, occurring in $36.4 \%$ of the patients, followed by atrial fibrillation occurring in $27.3 \%$ of patients, IE in $27.3 \%$, and AFT in $9.1 \%$.

RHD is the most common predisposing factor to IE in Africa. Retrospective/prospective hospital-based epidemiologic studies conducted in Nigeria, Morocco, and South Africa on patients with IE showed that $66.0 \%, 63.0 \%$, and $76.6 \%$ respectively had RHD as the underlying cause of cardiac lesions. ${ }^{5,34,35}$ Data collected in two studies from echocardiographic units of different tertiary centers in Nigeria reported that $8.7 \%$ and $8.5 \%$ of RHD patients had IE. ${ }^{22,8} \mathrm{AF}$ was found in $12.9 \%$ of the patients in one series, ${ }^{22}$ and in $10.1 \%$ in another series. ${ }^{8}$ 
The Heart of Soweto study also found AF in $10.0 \%$ of their patients with newly diagnosed RHD. ${ }^{1}$ It was not surprising that AFT was found in only one $(9.1 \%)$ patient because AFT is an unstable arrhythmia that rapidly turns to AF. Pulmonary hypertension was found to be the commonest complication of RHD in the echocardiographic study of RHD patients, affecting $72.1 \%$ of the patients. ${ }^{8}$

Some parameters and complications of RHD in hospitalbased epidemiologic studies are not comparable to studies solely based on echocardiography, as particular investigations included in the former will not have been encompassed in the latter. This fact may account for the variations in the frequencies of these complications.

The mitral valve was affected in $90.9 \%$ of our study patients as shown in Table 5, which is in keeping with the study done in Zaria, Nigeria, by Danbauchi et al, in which the mitral valve was involved in $97.0 \%$ of the patients in their series. ${ }^{23}$ Other studies also support this finding. ${ }^{1,2,8,24,37-40}$ The next most common valve involved was the aortic, which was affected in $36.4 \%$ of the patients. This finding is comparable with the study done in Port Harcourt, Niger Delta, in which $40.9 \%$ of the patients had aortic valve involvement. ${ }^{39}$ Next frequent were the tricuspid valve with $18.2 \%$ involvement and the pulmonary with $9.1 \%$ involvement. Tricuspid valve lesion occurred either as stenosis or regurgitation in combination with mitral, aortic, or pulmonary valve, but not alone, as shown in Table 3. The tricuspid valve involvement of $24.1 \%$ that was recorded by Essien et al is in agreement with the $18.2 \%$ found in this study. ${ }^{2}$ The pulmonary stenosis found in combination with other valvular lesions could be a coincidental congenital lesion, as the pulmonary valve is rarely affected. It is also worth noting the case of congenital discrete subaortic stenosis coexisting with mitral regurgitation in the patient with serial number 7; hence it is not uncommon to find congenital lesions coexisting with RHD. The mitral and aortic valves were both affected in $18.2 \%$ of the patients. The Port Harcourt study reported twice this percentage (36.6\%). ${ }^{39}$ Similarly, Essien et al reported 33.3\%. ${ }^{2}$ The involvement of more than two valves was also noticed, as shown in Table 5.

\section{Conclusion}

The very low prevalence of $0.16 / 1000$ for medical outpatient clinics and 1.2/1000 for cardiology clinic attendees showed a decline which must be sustained; at the same time we must focus on complete eradication as our goal. Late presentation is also still very common with multiple complications which worsen the chances of these patients who are still active and in their financially productive years. Two of the United
Nations' Millennium Development Goals ${ }^{40}$ to tackle, in order to eradicate this disease, are poverty and infections. SubSaharan Africa is bedeviled by many communicable diseases coupled with various economic constraints; prevention is the preferable option for the region.

The principles of the Drakensberg declaration ${ }^{26}$ of 2005 on the control of rheumatic fever and rheumatic heart disease in Africa continue to gain support through the spirited effort of the highly motivated Pan African Society of Cardiology in collaboration with WHO and the World Heart Federation. More support for health care workers is needed to ensure the eradication of RF and RHD from the African continent. If the developed countries achieved this goal more than 50 years ago, we can do the same.

The retrospective nature of the study was a limitation as information, investigation results, and other parameters were not available for a more comprehensive assessment of the new trend in morbidity and mortality of RHD.

\section{Acknowledgments}

We sincerely appreciate the efforts of Mr Oyetunde Gabriel Asa from the hospital's medical records department, who helped to retrieve case notes and all other information necessary to generate the data. We are also grateful for the assistance with statistical analysis of the data provided by Dr Esther Olufunmilayo Asekun-Olarinmoye and Dr Wasiu Olalekan Adebimpe of the Department of Community Medicine, College of Health Sciences, Osun State University, Osogbo, Nigeria. Finally we are grateful to the cardiology unit house officers for assisting with the data collection. The authors funded the study.

\section{Disclosure}

The authors have no conflicts of interest to declare in this study.

\section{References}

1. Sliwa K, Carrington M, Bongani M, Zigiriadis E, Mvungi R, Stewart S. Incidence and characteristics of newly diagnosed rheumatic heart disease in urban African adults: insights from the Heart of Soweto Study. Eur Heart J. 2009;31:719-727.

2. Essien IO, Onwubere BJ, Anisiuba BC, Ejim EC, Andy JJ, Ike SO. One year echocardiographic study of rheumatic heart disease at Enugu, Nigeria. Niger Postgrad Med J. 2008;15:175-178.

3. Beaton A, Okello E, Lwabi P, et al. Echocardiography screening for rheumatic heart disease in Ugandan school children. Circulation. 2012;125:3060-3062.

4. Ike SO. Echocardiographic analysis of valvular heart diseases over one decade in Nigeria. Trans R Soc Trop Med Hyg. 2008;102:1214-1218.

5. Ifere OA, Masokano KA. Infective endocarditis in children in the Guinea savannah of Nigeria. Ann Trop Paediatr. 1991;11:233-240.

6. Oli K, Asmera J. Rheumatic heart disease in Ethiopia: could it be more malignant? Ethiop Med J. 2004;42:1-8. 
7. Louw JW, Kinsley RH, Dion RA, et al. Emergency heart valve replacement: an analysis of 170 patients. Ann Thorac Surg. 1980;29: 415-422.

8. Sani MU, Karaye KM, Borodo MM. Prevalence and pattern of rheumatic heart disease in the Nigerian savannah: an echocardiographic study. Cardiovasc J Afr. 2007;18:295-299.

9. Akintunde AA, Opadijo OG. Late presentation of rheumatic heart disease: a justification for renewal of preventive methods? Pan Afr Med J. 2009;3:22.

10. Carapetis JR. The Current Evidence of the Burden of Group A Streptococcal Disease. Geneva: World Health Organization; 2004:1-57.

11. Carapetis JR, Steer AC, Mulholland EK, Weber M. The global burden of group A streptococcal diseases. Lancet Infect Dis. 2005;5:685-694.

12. Chopra P, Gulwani H. Pathology and pathogenesis of rheumatic heart disease. Indian J Pathol Microbiol. 2007;50:685-697.

13. Silwa K, Wilkinson D, Hansen C, et al. Spectrum of heart disease and risk factors in a black urban population in South Africa (the Heart of Soweto Study): a cohort study. Lancet. 2008;371:915-922.

14. Ogah OS, Adegbite GD, Akinyemi RO, et al. Spectrum of heart disease in a new cardiac service in Nigeria: an echocardiographic study of 1441 subjects in Abeokuta. BMC Res Notes. 2008;1:98.

15. Adebayo RA, Akinwusi PO, Balogun MO, et al. Two dimensional and doppler echocardiographic evaluation of 2501 patients presenting at OAUTHC, Ile-Ife, Nigeria. West African College of Physicians Abstracts. 36th Annual General and Scientific Meeting; 2012 Nov 4-8; Accra, Republic of Ghana.

16. Abengowe CU. Cardiovascular disease in Northern Nigeria. Trop Geogr Med. 1976;31:553-560.

17. Karaye KM, Sani MU. Factors associated with poor prognosis among patients admitted with heart failure in a Nigerian tertiary medical centre. A cross sectional study. BMC Cardiovasc Disord. 2008;8:16.

18. Ansa VO, Ekott JU, Bassey EO. Profile and outcome of cardiovascular admissions at the University of Uyo Teaching Hospital, Uyo- a five year review. Niger J Clin Pract. 2008;11:22-24

19. Onwuchekwa AC, Asekomeh GE. Pattern of heart failure in a Nigerian teaching hospital. Vasc Health Risk Manag. 2009;5:745-750.

20. World Health Organization. Rheumatic Fever and Rheumatic Heart Disease. Report of WHO Study Group. Geneva: World Health Organization; 1988:1-59.

21. Ahmed J, Mostafa ZM, Manzur HMM. Prevalence of rheumatic fever and rheumatic heart disease in rural Bangladesh. Trop Doct. 2005;35:160-161.

22. Grover A, Vijayvergiya R, Thingam ST. Burden of rheumatic and congenital heart disease in India: Lowest estimate based on 2001 census. Indian Heart J. 2002;54:104-107.

23. Danbauchi SS, Alhassan MA, David SO, Wammanda R, Oyati IA. Spectrum of rheumatic heart disease in Zaria, Northern Nigeria. Ann Afr Med. 2004;3:17-21.

24. Refat M, Rashad E, El Gazar A, et al. A clinic-epidemiologic study of heart disease in school children of Mnoufia, Egypt. Ann Saudi Med. 1994; $14: 225-229$.
25. Marcus RH, Sareli P, Pocock WA, Barlow JB. The spectrum of severe mitral valve disease in a developing country. Ann Intern Med. 1994;120: $177-183$.

26. Mayosi B, Robertson K, Volmink J, et al. The Drakensberg declaration on the control of rheumatic fever and rheumatic heart disease in Africa. S Afr Med J. 2006;96:246.

27. Rammelkamp CH. Rheumatic heart disease - a challenge. Circulation . 1958; 17:842-851.

28. Denny FW. T Duckett Jones and rheumatic fever in 1986. T Duckett Jones memorial lecture. Circulation. 1987;76:963-970.

29. Omokhodion SI. Management of patients with rheumatic fever and rheumatic heart disease in Nigeria - need for a national system of primary, secondary and tertiary prevention. SAfr Med J. 2006;96(Pt 2): $237-239$.

30. Nkomo VT. Epidemiology and prevention of valvular heart dieases and infective endocarditis in Africa. Heart. 2007;93:1510-1519.

31. McDonald M, Currie BJ, Carapetis JR. Acute rheumatic fever. A chink in the chain that links the heart to the throat? Lancet Infect Dis. 2004;4:240-245.

32. Chobanian AV, Bakris GL, Black HR, et al; National Heart, Lung, and Blood Institute Joint National Committee on Prevention, Detection, Evaluation, and Treatment of High Blood Pressure; National High Blood Pressure Education Program Coordinating Committee. The Seventh Report of the Joint National Committee on Prevention, Detection, Evaluation and Treatment of High Blood Pressure: The JNC 7 Report. JAMA. 2003;289:2560-2572.

33. Adedoyin RA, Mbada CE, Balogun MO, et al. Prevalence and pattern of hypertension in a semi-urban community in Nigeria. Eur J Cardiovasc Prev Rehabil. 2008;15:683-687.

34. Bennis A, Zahraoui M, Azzouzi L, et al. Bacterial endocarditis in Morocco. Ann Cardiol Angeiol (Paris). 1995;44:339-344.

35. Koegelenberg CF, Doubell AF, Orth H, et al. Infective endocarditis in the Western Cape Province of South Africa: a three year prospective study. QJM. 2003;96:217-225.

36. Padamavati S. Rheumatic fever and rheumatic heart disease in developing countries. Bull World Health Organ. 1978;56:543-550.

37. Strasser R, Rotto R. The control of rheumatic fever and rheumatic heart disease: an outline of WHO activities. WHO Chron. 1973;27:49-54.

38. Marijon E, Ou P, Celermajer DS, et al. Prevalence of rheumatic heart disease detected by echocardiographic screening. $N$ Engl J Med. 2007;357:470-476.

39. Akpa MR, Dodyi-Manuel S, Agada Z, Odia OJ. Rheumatic heart disease in Port Harcourt, Nigeria: clinical, demographic and echocardiographic features. Port Harcourt Medical Journal. 2012:6. Abstract.

40. un.org [webpage on the internet]. Millennium Development Goals United Nations; 2012. Available from: http://www.un.org/millenniumgoals/. Accessed May 5, 2013.
International Journal of General Medicine

\section{Publish your work in this journal}

The International Journal of General Medicine is an international, peer-reviewed open-access journal that focuses on general and internal medicine, pathogenesis, epidemiology, diagnosis, monitoring and treatment protocols. The journal is characterized by the rapid reporting of reviews, original research and clinical studies across all disease areas.

\section{Dovepress}

A key focus is the elucidation of disease processes and management protocols resulting in improved outcomes for the patient. The manuscript management system is completely online and includes a very quick and fair peer-review system. Visit http://www.dovepress.com/ testimonials.php to read real quotes from published authors. 